\title{
COVID-19 impact on doctors and health workers
}

\author{
Dr Rabindra Man Shrestha', Dr Arun Raj Kunwar² \\ 'Prof, Dept of Orthodontics, Kantipur Dental College, Kathmandu, Nepal \\ ${ }^{2} \mathrm{Head}$, Child \& Adolescent Psychiatry Unit, Kanti Children's Hospital, Kathmandu, Nepal
}

The present article probes the current situation of doctors and health workers in Nepal as the impact of COVID-19 pandemic. It mainly discusses the social, occupational and psychological effects on the professionals. The article also documents the global occurrences and data related to COVID-19 pandemic. Lastly, it enlists the key recommendations to decrease the spread of COVID-19 and mental health measures to protect the health of the healthcare workers.

Since the case of Corona virus disease (COVID-19) was reported in December 2019; the entire global community has been affected by the contagious disease concerning the public health and hampered all works of life. The World Health Organization declared COVID-19 as 'public health emergency of international concern (PHEIC)' in January 30, 2020 and 'pandemic' in March 11, 2020. In Nepal, the first case was reported in January 23, 2020 on a Nepali student returning from Wuhan, China. ${ }^{1}$ Till date a total of $25,734,475$ individuals have been infected and 856,599 have died globally, and 40,529 have been infected and 239 have died in Nepal. ${ }^{2}$

Doctors along with the health workers have been in forefront of the battle against COVID-19. They are the only source of hope and cure for the patients and family afflicted by this contagious disease. Health taskforce have been deployed in the COVID-19 wards and laboratories for direct medical care of the patients, which can risk their own lives. There are many reports of the spread of infection and death of the doctors and health workers due to COVID-19. As of April 15; 278 physicians have died with COVID-19 infection globally. ${ }^{3}$ The International Council of Nurses reported at least 260 nurses have died and 90,000 healthcare workers have been infected in the pandemic till May 2020. The Indian Medical Association declared the death of 198 doctors in India till August 8, 2020. ${ }^{4}$ According to Health Services Division; at least 91 health workers including doctors, nurses, paramedics and lab technicians deployed in front line of Covid-19 have been infected in Nepal till July 3, 2020. ${ }^{5}$ The first case of death of the health worker has been reported in Nepal; a Health Assistant from Mahottari district died due to COVID-19 on August $26,2020 .{ }^{6}$ These figures are being changed and updated periodically.

In this pandemic situation, many doctors and health workers are working longer than usual hours. Once healthcare personnel put on the protective gown and mask, they have to work for several hours without drinking water or taking a restroom break as the protective wares have to be discarded after each use. Many healthcare workers have isolated themselves from their family for a long time in a fear of infecting them. Frontline workers' risk of COVID-19 infection is made worst by the deficiency of personal protective equipment (PPE). Many hospitals are not providing adequate PPE's to the staff, thus many are buying protective gears at their own cost. ${ }^{7}$

In many health institutions doctors and other healthcare workers have been terminated from job or not being paid for months owing to hospital managements' economic crisis. Many staffs, especially the non-COVID-19 treating ones are compelled to stay on unpaid leave in academic institutions and teaching hospitals. In another instance, doctors and nurses have been fired or threatened for speaking about poor management and about the lack of protective equipment. ${ }^{8}$ In Russia; three doctors fell from the hospital window after making public complaints; two of them died. The cases were later reported as accident or suicide. ${ }^{9}$

Doctors and nurses have been spotted weeping in the hospital lobby over the adverse situation they had to face and the pain of watching patients die. They are feeling helpless to save the COVID-19 patients. They are compelled to make difficult decisions such as moving a patient off the ventilator or not able to provide the ICU 
bed. Such situations can cause psychological distress termed as 'moral injury'. It is similar to the experience of soldiers in wartime, which can lead to depression and post-traumatic stress disorder (PTSD). ${ }^{8}$ Many healthcare personnel express the symptoms of 'burnout' characterized by emotional exhaustion, withdrawal and cynicism. The burn-out is often due to overwork, stress and the condition that limit the interaction with the patients. ${ }^{8,10}$

The Kathmandu Post reported that the health workers deployed on the frontline of COVID-19 have not received extra allowance promised by the government. The Ministry of Health had earlier announced extra allowance equivalent to the salary. This allowance money is essential for additional expenses for many health workers who have been staying in hotels or hostels because of the fear of spreading the infection to their family and due to the threats and pressure from house owners and neighbors. At least twenty medical officers serving at Sukraraj Tropical and Infectious Disease Hospital, Kathmandu have been living in hotels for the last several months. The situation is even worse at private hospitals, where the staffs are forced to quit their job or accept the lessened salaries by half, despite the directives of Ministry of Health not to deduct the salaries or reject the jobs. ${ }^{11}$

In many places around the world, people have commended the doctors and healthcare workers for their dedication and work. In Europe; people in isolation have been seen standing on windows and balconies singing, cheering and applauding to praise the doctors and health workers every evening..$^{12}$ In contrast, COVID-19 has left the doctors and health workers more vulnerable for physical assault and psychological trauma. There are many instances; where doctors, nurses or other health workers have been assaulted. In neighboring India, angry locals threw stones at doctors and health workers who went to screen people for coronavirus in Indore city. Two female doctors were injured in the attack and had to be rescued by police. Doctors at a hospital in Hyderabad were allegedly attacked after a patient with co-morbidities died of COVID-19. ${ }^{13}$ In USA a health worker was punched on the face in a Chicago bus, another was doused with bleach in Philippines, medical staff at a hospital in Australia were deliberately coughed and spat on by the anxious patients waiting to be tested for the disease and, many health workers were physically attacked in Mexico. ${ }^{8}$
Similarly in Nepal, healthcare workers have been targeted by the house owners, neighbors, public, media and even by the police. Recently, residents of New Baneshwor, Kathmandu gathered to protest at a hostel where doctors and health workers of Civil Hospital resided as a fear of spreading the Corona virus in the locality. The big mob led by area chair (toll sudhar samiti) and ward secretary threatened the house owner that they would punish him if he continues to let them stay. Earlier, policemen physically assaulted three doctors returning home from Tribhuvan University Teaching Hospital duty during a lockdown period. Similarly, a doctor was assaulted at an isolation center in Biratnagar, an isolation ward was vandalized by a crowd in Sankhuwasabha, local people protested against doctor and vandalized the hospital in Chhapkaiya Birgunj, doctors were abused and demoralized in Bharatpur Chitwan by sticking bill against the doctors, health workers collecting the swab were not allowed to reside in local area in Ratnanagar Chitwan. ${ }^{14-16}$ These are only few representative examples.

Many healthcare workers are realizing that they have to pay a heavy price for doing their job, often with minimal protection from the fatal disease. Apart from high risk of infection, anxiety and being separated from their families, they are also increasingly dealing with social stigma, harassment and physical assault. Often physical attacks are preceded by verbal abuses, as doctors and nurses are blamed for spreading the disease. A resident at AlIMS-Bhopal was assaulted by a policeman while returning home from emergency duty. The policeman accused doctors responsible for spreading the disease. Similarly in New Delhi, a man attacked two doctors at a fruit shop after accusing them of spreading the virus. ${ }^{7}$ The health workers even have to face the discrimination as they were refused service in cafes, eateries and shops for working in hospitals and laboratories. ${ }^{11}$ While wearing on uniforms, a nurse was assaulted on boarding on a train and another was abused by petrol station attendant in Australia. In this connection, nurses and midwives are being suggested not wear scrubs or uniform outside the hospital. ${ }^{17}$

The incidents of threats and violent attack to the doctors and health workers are not the new event. The World Health Organization estimates up to $38 \%$ of the physicians worldwide have suffered physical violence during the work. One in seven in England and one in three in Australia admit that they had been physically attacked by patient or public in past one year. ${ }^{18} \mathrm{~A}$ female doctor 
was stabbed to death at a hospital in Beijing in 2019.19 Over $75 \%$ of Indian physicians admit that they have faced the threat of violence during their professional career. ${ }^{20}$ In Nepal, the incidence of group attacks and physical assaults on doctors, vandalizing of hospitals, and on-the-spot demand for the compensation after the death of a patient is increasing. The Nepal Medical Association had demanded to implement 'jail without bail' regulation, and the medical fraternity be given a due respect. The association sought a strict law that does not allow the release of those who physically assault the doctors and damage the hospital facilities. .1,22 $^{21}$

Similar episodes are being repeated in the current pandemic era more aggressively. These unfortunate occurrences are perhaps due to the psychological and emotional disturbances with the public during this pandemic period. Because of the uncertainty about the job, economic crisis, worries for the family and fear for own life; the humanity has probably been shelved over the past few months with the lockdown of normal works of life. Doctors and health workers in obvious white coats and colored scrubs are thus easy targets for the scared, aggrieved and frustrated people. Fear of contagion amplified by misinformation through some irresponsible social sites and media appears to be promoting more violence during this pandemic.

An article in BMJ warned that the healthcare staffs are at increased risk of mental health problems and moral injury when dealing with the COVID-19 pandemic. A study on 1257 healthcare workers involved in various fever clinics and COVID-19 wards in China showed that $70 \%$ of healthcare workers reported the symptoms of depression, anxiety, insomnia, and distress. ${ }^{23}$ Protecting the mental health of healthcare workers is necessary not only to reduce the psychological suffering of these workers but also to reduce the condition that threatens the ability and preparedness to perform the best of their duties and effectiveness of the healthcare system. ${ }^{24}$

Besides rigidly obeying the safety guidelines and practicing the infection control protocol; the most practicable way to protect the doctors and health workers from contagious COVID-19 is the optimal supply and use of PPE and to improve the health care delivery system with preparedness for contingency. The World Health Organization has given the following key recommendations to decrease the spread of COVID-19 among healthcare workers: ${ }^{25}$
- Training healthcare workers to identify respiratory diseases

- Providing increased access to personal protective equipment

- Providing psychological support to health workers

- Routinely conducting hospital surveillance

- Recognizing that every healthcare system can have gaps

The keys to prevent the physical assault and psychological trauma to the doctors and health workers are to create public awareness, retain selfdetermination among the healthcare workers, and practice good communication skill. Conscious to the strain on medicos, there should be helpline and moral support from the authorities. The mental health experts at King's College London suggested following measures to protect the mental health of healthcare staffs: ${ }^{23,26}$

- Healthcare managers need to proactively take steps to protect the mental wellbeing of staff

- Managers must be frank about the situations staff are likely to face

- Staff can be supported by reinforcing teams and providing regular contact to discuss decisions and check on wellbeing

- Once the crisis begins to recede, staff must be actively monitored, supported, and, where necessary, provided with evidence based treatments.

During this crisis of pandemic, it is necessary for all to exhibit kindness, humanity and solidarity. It becomes everyone's basic responsibly and gesture to support the medical personnel and help save people's lives. Doctors and health workers should be treated with respect and appreciation, and give due recognition of their precious role in health emergency. As Jordi Raich, the Head of the ICRC regional delegation rightly pointed out, "The heroes of this pandemic are not film stars, but health personnel: doctors, nurses, paramedics and hospital cleaners. They are risking their health and that of their families to care for us and to heal us. ${ }^{27}$ 


\section{REFERENCES}

1. Health Sector Emergency Response Plan. COVID 19 Pandemic. Government of Nepal Ministry of Health and Population. May 2020. https://www.who.int/docs/default-source/nepal-documents/novel-coronavirus/health-sector-emergency-response-plan-covid-19endorsed-may-2020.pdf?sfvrsn= ef831f44_2.

2. https://www.worldometers.info/coronavirus/ (1 September 2020 10:07 PM, date last accessed).

3. Ing EB, Xu Q(A), Salimi A, Torun N. Physician deaths from corona virus (COVID-19) disease. Occupational Medicine. July 2020; 70:5:370374. https://doi.org/10.1093/occmed/kqaa088.

4. Impact of the COVID-19 pandemic on healthcare workers [Online]. https://en.wikipedia.org/wiki/Impact_of_the_COVID-19_pandemic_ on_healthcare_workers. (27 August 2020, date last accessed).

5. 91 health workers across the country have been infected with coronavirus so far [Online]. The Kathmandu Post. Last updated: 3 July 2020. https://kathmandupost.com/health/2020/07/03/91-health-workers-across-the-country-have-been-infected-with-coronavirus-sofar. (27 August 2020 date last accessed).

6. Nepal reports 1st Covid-19 death of health worker [online]. Online khabar English Ed. Last updated: 31 August https://english. onlinekhabar.com/nepal-reports-1 st-covid-19-death-of-health-worker.html (31 August 2020, date last accessed).

7. Covid-19: How healthcare workers are paying a heavy price in this battle [Online]. The Economic Times. Last updated: 12 April 2020 . https:// economictimes.indiatimes.com/news/politics-and-nation/covid-19-how-healthcare-workers-are-paying-a-heavy-price-in-this-battle/ articleshow/75099895.cms?utm_source=contentofinterest\& utm_medium=text\&utm_campaign=cppst. (27 August 2020, date last accessed).

8. Health workers become unexpected targets during covid-19 [Online]. The Economist. Last updated: 11 May 2020. https://www.economist. com/international/2020/05/11/health-workers-become-unexpected-targets-during-covid-19. (27 August 2020, date last accessed).

9. Three Russian doctors have fallen from hospital windows in two weeks, amid reports of dire conditions. The Washington Post. Last updated: 7 May 2020. https://www.washingtonpost.com/world/europe/three-russian-doctors-have-fallen-from-hospital-windows-intwo-weeks-amid-reports-of-dire-conditions/2020/05/06/c3ca73f4-8f88-11ea-a9c0-73b93422d691_story.html. (27 August 2020, date last accessed)

10. https://newsnetwork.mayoclinic.org/discussion/taking-a-stand-against-burnout-in-health-care/. (27 August 2020, date last accessed).

11. Health workers deployed at Covid-19 frontline deprived of their allowances [Online]. The Kathmandu Post. Last updated: 7 June 2020. https://kathmandupost.com/national/2020/06/07/health-workers-deployed-at-covid-19-frontline-deprived-of-their-allowances. August 2020, date last accessed).

12. Europeans Sing Praises of Health Workers from their Windows [Online]. Associated Press. Last updated: 24 March 2020. https://www.voanews. com/science-health/coronavirus-outbreak/ europeans-sing-praises-health-workers-their-windows. (27 August 2020, date last accessed).

13. Attacks on doctors, healthcare workers rise amid COVID-19 pandemic [Online]. NDTV. Last updated: 2 April 2020. https://www.ndtv. com/india-news/attacks-on-doctors-healthcare-workers-rise-amid-covid-19-pandemic-2204547. (27 August 2020, date last accessed).

14. Locals protest against doctors and nurses stay in hostel of Baneshwor [Online]. Nepal Monitor. Last updated: August 23, 2020. https:// nepalmonitor.org/reports/view/30805. (27 August 2020, date last accessed).

15. Nayapatrika daily (in Nepali). Last updated: 23 August 2020. https://www.nayapatrikadaily.com/epaper/23-08-2020. (23 August 2020 date last accessed).

16. Police Take Action Against DSP Lamsal For 'Beating' Doctors [Online]. The Rising Nepal. Last updated: 16 April 2020. https:// risingnepaldaily.com/mustread/police-take-action-against-dsp-lamsal-for-beating-doctors. (27 August 2020, date last accessed).

17. NSW nurses told not wear scrubs outside of hospital due to abuse over coronavirus fears [Online]. ABC. Last updated: 5 April 2020. https://www.abc.net.au/news/2020-04-05/nsw-nurses-midwives-abused-during-coronavirus-pandemic/12123216. (27 August 2020, date last accessed)

18. Violence against health workers [Online]. World Health Organization. https://www.who.int/violence_injury_prevention/violence/workplace/en/

19. Man stabs female doctor to death in Beijing hospital [Online]. China Daily. Last updated: 24 December 2019. http://global.chinadaily. com.cn/a/201912/24/WS5e01 aa74a310cf3e355804da.html. (27 August 2029, date last accessed).

20. Over $75 \%$ of doctors have faced violence at work, study finds [Online]. The Times of India. Last updated: 4 May 2015 . https://timesofindia.indiatimes. com/india/Over-75-of-doctors-have-faced-violence-at-work-study-finds/articleshow/47143806.cms. (27 August 2020, date last accessed)

21. Rokaya D, Humagain M. Doctors under Threat and Physical Assault. Thieme Open Access. June 2020. DOI https://doi.org/ 10.1055/s-0040-1710137.

22. Doctor's on strike [Online]. Nepali Times. Last updated: 22 September 2017. http://www.nepalitimes.com/blogs/thebrief/2017/09/22/ doctors-on-strike/. (27 August 2020, date last accessed).

23. Greenberg N, Docherty M, Gnanapragasam S, Wessely S. Managing mental health challenges faced by healthcare workers during covid-19 pandemic. Br Med J. March 2020. https://www.bmj.com/content/368/bmj.m1211.

24. Cooch N. The psychological impact of COVID-19 on physicians: Lessons from previous outbreaks. Practice Update. June 2020. https:// www.practiceupdate.com/content/the-psychological-impact-of-covid-19-on-physicians-lessons-from-previous-outbreaks/100995.

25. How to protect the wellbeing of healthcare staff in the COVID-19 crisis [Online]. World Health Organization. Last updated: 4 June 2020 . https:// www. who.int/emergencies/diseases/novel-coronavirus-2019/advice-for-public?gclid=CjwKCAjwkJj6BRA-EiwA0ZVPVgZVkAuFzk0NFhNKzPGuM1Baz53n3DFMb_KEQDKxilcLDNTSetQMhoChkcQAvD_BwE. (27 August 2020, date last accessed).

26. King's College London. News Centre. Last updated: 26 March 2020. https://www.kcl.ac.uk/news/ensuring-the-mental-health-ofhealthcare-workers-in-the-covid-19-pandemic. (27 August 2020, date last accessed)

27. Health workers are saving lives and must be treated with respect to beat COVID-19: ICRC and Mexican Red Cross [Online]. Last updated: 8 May 2020. https://www.icrc.org/en/document/healthcare-workers-are-saving-lives-during-pandemic-they-must-be-treated-respect-ifvirus. (27 August 2020, date last accessed). 